\title{
Disaster Mitigation Information in Football Matches: Fans Perspective
}

http://dx.doi.org/10.25008/wartaiski.v2i02.37

\author{
Fajar Junaedi ${ }^{1}$, Filosa Gita Sukmono ${ }^{2}$ \\ ${ }^{1,2}$ Universitas Muhammadiyah Yogyakarta \\ Jl. Brawijaya, Geblagan, Bantul, Yogyakarta 55183 - Indonesia \\ Email korespondensi: fajarjun@umy.ac.id
}

\begin{abstract}
The study focuses on problems of disaster mitigation information in football matches and the implications to audiences'safety. The study uses study case method. The data collection is performed using in-depth interview, observation, and literature review; and the informant selection applies purposive sampling or criterion-based selection. Informants picked are fans of PSIM Yogyakarta, Persiba Bantul, and Persebaya Surabaya who experienced disasters in the stadiums. The study demonstrates, based on fans experiences, that various factors are responsible for outbreaks in football matches, namely the absence of information on disaster mitigation, the unprofessionalism of the organizers and securities in managing possible disasters, the insufficiency of the stadium architecture to deal with disasters, and the inadequacy of medical facilities in emergencies. The way forwards which are proposed is that, firstly, stadium construction should be designed by heeding disaster mitigation consideration for the sake of individuals' well-being in the stadium. Moreover, the organizers, including the securities, should be more professional in running the matches. Finally, appropriate facilities for preventing disasters should be provided.
\end{abstract}

Keywords: Disaster mitigation, football fans, information, safety.

\section{INTRODUCTION}

A football match is an event that involves thousands of audiences, and, with the number of people coming in the same place, a stadium allegedly becomes a location which is prone to disaster. One of the worst tragedies in the history of football took place in Heysel Stadium, Belgium (1985), causing 39 audiences passed away and other 600s injured. The tragedy, which was responsible for the collapse of stadium's wall, started when Liverpool fans charged Juventus fans in the Champion League final. Another appalling outbreak was a riot in Port Said Stadium, Mesir (2012), leading 79 spectators died and other 1000s hurt after the fans of al-Masry attacked al-Ahly.

After many catastrophes in England's football between the 1970s and 1980s, notably after the Hillsborough tragedy, the football federation and the England government approved a set of policies in the football management for preventing accidents in the stadiums. After the early 1990s, England match management policy had transformed. Fans violence, especially hooliganism, successfully was pressed. Concurrently, the physical construction of many stadiums was reconstructed for securing the safety of audiences. As a result, England football has developed to be one of the most prestigious football competitions in the world.

However, while football match management in England has improved professionally, the opposite is the case in Indonesia. Violence occurring in the stadiums becomes continuous phenomena and has resulted in a dramatic number of fatalities. A stadium that ideally should be a safe amenity to enjoy a football game turns to be a disastrous place. The following is a set of evidence demonstrating that Indonesian football match management is murky and disaster-prone.

Table 1. Disasters Related to Football Match in Some Indonesian Stadium

\begin{tabular}{lll}
\hline No. & Date & Disaster description \\
\hline 1. & June 3,2012 & After the match between Persebaya and Persija (IPL), there was \\
& & $\begin{array}{l}\text { a conflict between the fans and the police. The police fired tear } \\
\text { gas to the fans stands, imposing the fans to run away. The }\end{array}$ \\
\cline { 3 - 3 } & &
\end{tabular}


stadium corridor that was narrow and the absence of information on disaster mitigation caused the audiences cramped in the gate BB. A Persebaya supporter drew his last breath after this accident.

2. October 22,2014

3. July 23,2016

4. $\quad$ October 11,2017

5. June 15,2018
After the match of Persis Solo vs. Martapura FC in the Manahan Stadium Solo, the supporters poured to the field. The police halted them using tear gas and the violence between the police and fans perpetuated until outside the stadium. A fan of Persis Solo found died with a shot wound.

After the match of Persis Solo vs. Martapura FC in the Manahan Stadium Solo, the supporters poured to the field. The police halted them using tear gas. The violence between the police and fans perpetuated until outside the stadium. A fan of Persis Solo found died with a shot wound.

Turmoil happened not long after the match between Persita and PSM Medan in Mini Persikabo stadium, Bogor, finished. A fan died after being beaten by some criminals who were suspected soldiers.

The police fired nine projectile tear gas for stopping Arema fans from interfering the match between Arema FC and Persib Bandung. Reported by three newspapers, three projectiles were launched to the stands - breeding panic to the viewers who run out of the stadium. The management of Arema FC publicized that 214 people should be treated medically and a fan passed away.

Source: The data is obtained from news and fans who were in the location during the disasters. The information is not intended to be exhaustive for covering any outbreaks in every Indonesian football matches and divisions.

The table illustrates that football fans are the most numerous groups which should put up with the disasters in the stadium during the match holds. It is the reason for which information coming from football fans on disaster mitigation management in the stadium is vital.

\section{THEORETICAL FRAMEWORK}

Research on disaster mitigation and communication in Indonesia has been conducted by some researchers, ranging from as Setio Budi HH (2012) on disaster communication, Etika Emilayanti et al. (2016) on disaster mitigation management with information technology in Ciamis, to Indarti Komla Dewi and Yossa Istiadi on disaster mitigation in Tasikmalaya traditional society. Their research focus on how disaster communication was conducted in Indonesia. However, the research mentioned above has not covered disaster mitigation in football, particularly from the audience perspective, so that this research will complete a space which has not fulfilled by other studies.

Research on football mitigation have been conducted in England after any football disasters in 1960's until 1980's. Research by Paul Draby, Martin Jones and Gavin Mellor (2005) show stadium-related football disasters have undoubtedly been the most deadly, in terms of loss of life, which have occurred around the game. The disaster did lead to the first safety regulation of sports grounds in the UK but it took the 1989 disaster at Hillsborough for the country's top stadia to be totally overhauled. The move to all-seater grounds in the English game's top two divisions may have been underpinned as much by the desire to eradicate hooliganism as it was to ensure the safety of fans but it had a radical impact on not only the game's built environment but also the whole culture of fandom. Ticket prices escalated and leading stadia became more sanitised, maybe even quieter.

\section{METHODOLOGY}


e-ISSN: 2686-0724 - p-ISSN: 0853-4470 - Vol. 02, No. 02 (2019), pp. 124-132

The research uses case study method. Accurately, the data collection is performed using indepth interview, observation, and literature review. The in-depth interview is flexible and open, does not have a fixed structure, not completed within a formal situation and able to be carried out more than one time. The questions are formulated and prepared in the interview guide, and it is prioritized to be asked in the interview before developed to other possible queries, as well as accurately noted it down (Neuman, 2000: 277). The informant selection applies purposive sampling or criterion-based selection. In this research, Informants picked are fans of PSIM Yogyakarta, Persiba Bantul, and Persebaya Surabaya, who experienced disasters in the stadiums.

Data reduction in this research is a part of a selection, focusing, simplification, and abstraction process of the interview transcript and field note. The display is an assembly of information and description in the form of narration, enabling the conclusion to be drawn. Conclusion drawing will be verified so that it can be accounted for. Therefore, repetitive activities are essential for confirmation and fast re-tracking. The verification is also conducted with other data replication and accuracy enhancement so that the research conclusion can be more corroborated and reliable (Sutopo, 2000: 90-93).

\section{RESULT AND DISCUSSION}

An attempt to reduce the effects or risks of disaster refers to Indonesian act number 24 of 2007 concerning disaster. It groups the activities into the pre-disaster phase, during-disaster phase, and post-disaster phase. A disaster according to this act is an or sequence of event threatening and disturbing lives and business of society affected, including fatality, environmental degradation, and mental effects, whether coming from nature or man. Disaster mitigation, by contrast, is a set of attempts ranging from a selection of disaster-prone developmental policies, disaster prevention and emergency actions, to rehabilitation. Moreover, disaster prevention activity is a set of works conducted to eliminate and or reduce disaster threats. This prevention is carried out with disaster mitigation. A selection and a strategy of accurate disaster mitigation are critical in hampering or dipping the rate of possible disaster damage and victims (Hasnawir, 2012:21).

\section{Football Disaster in Fans Perspective}

In an Indonesian football match, football fans who are interviewed reflect some problems which show that match organizer, football federation (football association of Indonesia), and the operator of Indonesian league poorly perform effective strategies for keeping away the risk of disasters. In the old stadium, a disaster mitigation strategy has not been executed since the stadium designing, shown by the low number of evacuation gate. Specifically, the followings are the condition within football stadiums during football match witnessed and experienced by football fans.

An attempt to reduce the effects or risks of disaster refers to Indonesian act number 24 of 2007 concerning disaster. It groups the activities into the pre-disaster phase, during-disaster phase, and post-disaster phase. A disaster according to this act is an or sequence of event threatening and disturbing lives and business of society affected, including fatality, environmental degradation, and mental effects, whether coming from nature or man. Disaster mitigation, by contrast, is a set of attempts ranging from a selection of disaster-prone developmental policies, disaster prevention and emergency actions, to rehabilitation. Moreover, disaster prevention activity is a set of works conducted to eliminate and or reduce disaster threats. This prevention is carried out with disaster mitigation. A selection and a strategy of accurate disaster mitigation are critical in hampering or dipping the rate of possible disaster damage and victims (Hasnawir, 2012:21).

In an Indonesian football match, football fans who are interviewed reflect some problems which show that match organizer, football federation (football association of Indonesia), and the operator of Indonesian league poorly perform effective strategies for keeping away the risk of disasters. In the old stadium, a disaster mitigation strategy has not been executed since the stadium designing, shown by the low number of evacuation gate. Specifically, the followings are the condition within football stadiums during football match witnessed and experienced by football fans. 


\section{The absence of mitigation disaster information in the stadiums}

A football match is a pursuit which might invite thousands of people to gather in a stadium. In Yogyakarta, there are three stadiums which capable of accommodating 25.000 audiences, namely Maguwaharjo Stadium, Sultan Agung Stadium, and Mandala Krida Stadium in Yogyakarta. During the research, Mandal Krida Stadium is under construction for expanding the capacities and facilities. In other cities, such as Surabaya a stadium called Gelora Bung Tomo Stadium which can accommodate more people, around 50.000, is constructed.

Unfortunately, both in the older and newer stadium, the fans contend that they rarely find disaster signs, such as evacuation and meeting point signpost. Indeed, there is no information from the master of ceremony either before the game started on emergency exit which can be passed through, such as available exit gate. In the management of disaster information, there are two necessary announcement suggestions regarding disaster information: firstly, the delivery should be fast, accurate, consistent, and understandable. Secondly, the advice should be practicable (Haddow and Haddow, 2009:4). However, both mentioned advice is absent in the football matches which have watched by the informants. An informant state that:

Mostly, almost there is no disaster signpost. I have watched football matches many times, whether as a football fan or a journalist. I saw no signpost at all, such as evacuation door which we can go through it when a disaster comes. Only in Patrio Stadion (Bekasi), I found a signpost about disaster mitigation. (AR)

Likewise, another informant reveals a similar experience:

I several times enjoy football matches of PSIM in the stadium, whether for home or away match. The worst experience I underwent is turmoil in the old stadium in the small city. I also put up with unrest when PSIM had a game to Batan. In the beginning, PSIM fans are not satisfied to referee decision who allow Batang player to play violently. A throwing accident between fans then is irresistible. The police stopped us and not authorized anyone to escape since the supporters of the opposing team were waiting outside. In the same time, the police launched tear gun to us. (AW)

Furthermore, the informants coming from Surabaya tells this:

GBT (Gelora Bung Tomo) Stadium is vast, but there is no signpost in or around the stadium. It becomes worse because access to the stadium is limited. Only two paths are heading to the stadium, and those are too narrow for thousands of people. Indeed, the evening matches are held at the same time with the rush hours." After the game, we usually stick in the congestion for hours. Stadium corridors are also dim. In an emergency, it can be dangerous. (HG)

According to football fans, once unrest took place, panic will spread to all spectators in the stadium. Generally, based on experience, fans have three choices to shield themselves, running to the exit gates, heading to the center of the field, and jump over the stands' fences. The informants of the research describe that they jump over the 5 meters fences to hamper unrest during the outbreak in the match between Persibat Batang and PSIM Yogyakarta in M. Sarengat Stadium, July 23, 2016.

\section{The unprofessionalism of the football match organizers and securities in managing disaster mitigation}

A disaster which happens in an Indonesia football match is more dominated with human problems, namely riot. It realizes through two patterns of conflicts. Firstly, unrest between different football fans. The differences here is the difference in teams supported, or communities joined. Regarding the latter, they still could conflict although they support the same team. Secondly, a riot which involves the police and securities safeguarding the match.

Based on the interview, the fans contend that the match organizers and securities are not professional even from the open gate. They frequently witness the duty officers letting audiences into the stadiums even without tickets. It prompts the integrity of the organizers to wear off. An informant narrates his experience when entering the open gate of a stadium: 
e-ISSN: 2686-0724 - p-ISSN: 0853-4470 - Vol. 02, No. 02 (2019), pp. 124-132 Sultan Agung Stadium used to possess an effective gate-security. Each audience was checked one by one thoroughly. However, since Persiba Bantul was degraded to Liga 3 (third division), the checking process started not to detail anymore. Probably because the number of audiences plummeted, only two thousand people on average. (YA)

Regarding the integrity of the gate officers during the check-in, the researcher used to experience the same experience when Persija Jakarta had a game with PSM Makasar. Persija is a club coming from Jakarta, but they should move their home match to Sultan Agung Bantul Stadium in Liga 1 2019. When the researcher entered the stadium through the VIP south gate, the officer did not check the audiences who passed in. The researcher who, on that time, acted as an ordinary person was not monitored carefully. They only scanned the ticket. Furthermore, the officers allowed four people to the stadium without a ticket.

The conduct, which allows the non-ticket audience to the stadium, actuates football fans to have fewer respects to the match organizers. One of the informants shares his experiences:

The offices often allow people they recognized to the stadium. Indeed, they were allowed to VIP stands.

It is one of the reasons there are throwings to the players from VIP stadium. (MSW)

Safety checking process only processed thoroughly in the national matches or matches involved teams from first division (Liga 1) while local competitions, such as in the second or third division (Liga 2 and 3), the securities do not investigate items carried by the audiences. Consequently, dangerous tools, such as flare and smoke bomb can infiltrate. The unauthorized devices are smuggled to the stadium by the woman fan, and because the woman officers who scan them are rare, they can pass effortlessly. SM is the informant which depict the situation:

We often catch Indonesian football fans smuggle flare and smoke bomb to the stadium by giving the items to woman fans. Mostly, because the officers are male, they are likely not to check the women. Football fans exploit it to passed flare and smoke bomb to the stadium. The worse is if the fans smuggle melee weapon. (SM)

However, the essential and exemplary experience is performed by Surabaya police officers. The informant narrates that:

In Gelora Bung Tomo Stadium, the police check the audiences multiple times. There are three layers of checking. The first ring is in the outskirt of the stadium. The officers discriminate the audience with and without a ticket. If the officers find a man without a ticket, they will stop him. The second ring is similar to the previous layer. Finally, in the last ring, the officers check the ticket as well as the items carried. It enables the stadium dispense with the no-ticket audiences. Surabaya police officers say that they can secure all matches in Surabaya. However, other regional police cannot easily always apply it. Everyone knows the reputation of Bonek in the police perspective. Surabaya police depend on their leader to approach Bonek. If the plan runs well, the relation between Bonek and police will be peaceful. Otherwise, another riot can happen.

Another striking problem is that the officers in charge who safeguard the match directing themselves to the field and not not to the stands. They do not monitor the audiences whole-heartedly. As a result, there is no early prevention towards outbreak which occurs in the stadium. The police generally only make a move after the riot palpable. Indeed, the fans say that the police often without further consideration fire the tear gas instantly. It causes panic in the stands. The informant tells:

When unrest happened in Batang, the police recklessly launched the tear gas. Fans sitting in the stand get fired without any warning. What follows is that the panic. (SM)

Another informant also tells the researcher that:

They should reconsider the function of tear gas during the football match. The police love to fire tear gas to the fans. They should know that in the stands there are not only fans but also ordinary audiences. There are girls and children which easily can be the victims of the panic initiated by tear gas. (AW) 
e-ISSN: 2686-0724 - p-ISSN: 0853-4470 - Vol. 02, No. 02 (2019), pp. 124-132

It suggests that a better SOP (Standard Operation Project) in launching tear gas in the stadium is indispensable. The use of tear gas for combating a riot can induce a new disaster in the stadium. The panic of the audience in the grandstand resulted from tear gas is seemingly inevitable. However, another fan interviewed also states that:

There is no SOP on disaster mitigation in the stadium. The organizers neglect any potency that can make a disaster to be more spread. Ideally, the organizers should run the game appropriately by formulating an effective SOP. (AK)

\section{The insufficiency of the stadium construction to deal with disaster}

The informants mention that older stadiums are not designed for facing disasters. The limited accesses of entering gates breed the spectators who wish to save themselves are prone to be cramped in the corridor. Moreover, the stair steps in the grandstand leading to the main gate are limited. Consequently, those people inclined to fall from the stairs because of panic.

Another way to save one's life is by running to the center of the field. However, the high fence which border stands and the pitch as well as the long gap between the stands and the pitch, make this choice to be risky. However, the informant explains that this is the most feasible option to take if a disaster occurs. The reason is that, when there is a riot between fans which involve the police, the opponent fans normally will throw rocks and other solid items to the stands while the police fire the tear gas to the football fans. With this in mind, reaching the center of the field is reasonable because it will dispense with those detrimental possibilities. Unfortunately, there is no accessible emergency exit to that place. It is emphasized by one of the informants who are ignorant about the issue:

We did not know which routes are emergency evacuations. In a panic, we only rely on our intuition, when we are saving ourselves. (AR)

Another informant argues that human instinct is dictated to run to the open space:

When an outbreak comes, human logic leads us to a vast area. In a stadium, when a disaster interrupts, the audiences and fans are likely to run to the field to protect themselves. The problem is that between the stands and the pitch, high fences are planted and there is no evacuative route available. (YP)

Actually, at some stadium, the emergency exit is provided. Consider Maguwoharjo Stadium as an example. Based on the researcher observation, there is a big gate which can be passed through to the southwest and northwest. Unfortunately, those gates tend to be closed and used for the parking lot of bus players and fire engine.

However, it is not necessarily the case. Another informant from Surabaya expressed a different opinion:

It is dangerous if the gate to the side of the stadium is unlocked. The audience coming from outside can freely enter the stadium. Besides, the fans that are struck back by the police can repeatedly infiltrate to the stadium. It is the experience resulted from the match between Persebaya and Kalteng Putra in the Gelora Bung Tomo Stadium during Liga 2. The audiences which should be outside come into the stadium once more through the side gate. (HG)

That difference implies that concerning the ideal status of the evacuation gates, either closed or open, depending on the situation. For natural disaster, the organizers should unlock the gates. By contrast, for humans' outbreak, such as unrest, the decision should be weighed up. Analyzing sociological aspects of supporter conflict is essential before opening the emergency gate.

\section{The inadequacy of medical facilities in emergencies}

One of the informants in the research is both football fans and sports journalist. He shares his appalling experience when watching a football game. A minute before the match between Persibat Batang and PSIM match was over, a riot, which involves fans of both sides and the police, started.

The police fired tear gas to the fans, and it caused a panic. The informant reflects his experience of dying: 
That person had asthma. In effect of the tear gas fire, his asthma reappeared. Fortunately, the surrounding fans gave him first aid by looking for an oxygen tank. The informant giving help to AR shares his story:

We saved AR by looking for an oxygen tank. There was no cylinder in the ambulance. We brought AR out of the stadium. Some friends seek an oxygen cylinder to the nearest medical facilities. Fortunately, a friend succeeded in getting it. AR finally can be saved (SM)

Based on SM's experience in aiding SM, it can be described that firstly SM went to the ambulance first but did not find first aid medical tools which can ameliorate AR's asthma. They, then, looked for an oxygen tank but the ambulance did not provide it. Eventually, they found it in the nearest medical facility. This memorable event demonstrates that the match organizers still ignores medical facilities.

By contrast, the informant from Surabaya illustrates the readiness of Surabaya football fans in dealing with a disaster.

We are Bonek (Persebaya's loyal supporter) created Bonek Disaster Emergency Unity. It comprises of well-trained Bonek on giving medical aid to fans needed. The many fans of us initially inspired this idea because of the increased number of people faint during the match. Generally, they came several hours before the game began, especially in the big game. The medical staff was absent in the stands. We should carry them first although they urgently call for emergency aid. From that accident, we initiated to make disaster unit. Besides for the game, the same group used to land in many regions in Indonesia, such as in Nusa Tenggara Barat and Palu after the earthquake. (HG)

That information shared by the last informant can be deemed a decent step in disaster mitigation management in the stadium. Fans have concerned with safety aspects in the stadium. Based on disaster literacy, Indonesian football fans have realized the significance of disaster mitigation in the stadium.

\section{A Call For Enhancing National Disaster Information Management during Football Game}

England is an exemplary country for this issue because it can transform the face of its national football. Tragedies occurred in the UK after World War II, mostly dominated by the violence of football fans, successfully has been reduced. England a country that in the 1970s to 1980s vastly recognized because of the abuse of hooliganism has succeeded in changing the face of the national football to industrial football. England football competition since 1990 to date has transformed into modern football with remarkable numbers of sponsors and lower numbers of violence.

Referring to England experience, disaster information management in Indonesian football games should be improved enormously. It does not only involve PSSI but also various stakeholders because the government and not club own most of the Indonesian stadiums. It is the reason the government role is vital.

The table number 2 is the recommendation for enhancing disaster mitigation information management in the stadium.

Table 2. Recommendation for enhancing disaster mitigation information management in the stadium

\begin{tabular}{|c|c|c|c|}
\hline No. & Stakeholder & Policy & \\
\hline 1. & PSSI & & $\begin{array}{l}\text { Regulation and its enforcement on mitigation in } \\
\text { football matches }\end{array}$ \\
\hline 2. & League Operator & & $\begin{array}{l}\text { Conducting regular checking on disaster facility and } \\
\text { signpost in the stadium } \\
\text { Training for the match organizers to deliver mitigation } \\
\text { information }\end{array}$ \\
\hline 3. & Match organizers & & $\begin{array}{l}\text { Detail checking process to all audiences entering the } \\
\text { stadium }\end{array}$ \\
\hline
\end{tabular}


- Layered checking system before the audiences come into the stands

- Announcing information regarding disaster mitigation before the match, such as emergency evacuation, exits, and etcetera.

4. The government

5. The security

6. Fans
- $\quad$ Building stadium considering disaster mitigation

- $\quad$ Building stadium heeding disable users

- $\quad$ Layered checking to all audiences before entering the stadium

- Maximalizing preventive approaches toward football riots

- $\quad$ Ensuring not to carry melee and dangerous weapons

\section{CONCLUSION}

Indonesian act number 24 of 2007 on disaster states in clause 34 that disaster mitigation execution consist of no-disaster situations and (b) in disaster-potential situations. Football match involving thousands of spectators is prone to disaster. Therefore, a football match should manage with well-planned disaster mitigation for protecting all human beings within the stadium. Players and the staff, match organizers, audiences, fans, and the security, as well as journalists, are the element which always in the stadium during the match. Their safety should be concerned so that there are no more victims because of a disaster.

Based on fans experience which witnesses disaster situation, various factors are responsible for the outbreaks, namely the absence of information on disaster mitigation, unanticipative organizers and securities on possible disasters, unimmunized stadium architecture from disasters, and inadequate medical facilities. These factors are mutually related which make the number of victim increase.

Some reservations should be resolved in the next football match to address the problem mentioned. Firstly, the stadium construction should be designed by paying heed disaster mitigation for all individuals in the stadium. The construction should provide seating, one seat for one audience, for avoiding over-capacity, a condition that is prone to disaster. Gate for evacuation should be prepared as well as with the signpost of meeting point and emergency evacuation that should be legible in the emergency. Secondly, the organizers, including the securities, should be more professional in running the match. Audiences and fans checking that enter the stadium should be more cautious and detail. Before the game, information regarding disaster mitigation, notably about the activities should be done by the people inside the stadium, emergency exit, and meeting point should be announced clearly. Finally, appropriate facilities for preventing disasters should be provided. Ambulances with complete medical and appropriate facilities and fire engine should be available and ready before, during, and after the match.

\section{REFERENCES}

Budi HH, Setio (2012). Komunikasi Bencana: Aspek Sistem (Koordinasi, Informasi dan Kerjasama), Jurnal Aspikomi, 1(4), 363-371.

Darby, Paul, Johnes, Martin, and Mellor, Gavin (2005). Football Disasters: A Conceptual Frame, in Darby, Paul, Johnes, Martin \& Mellor, Gavin (ed). Soccer and Disaster: International Perspective. London and New York: Routledge

Emaliyawati, Etika, Ayu Prawesti, Iyus Yosep, \& Kusman Ibrahim (2016). Manajemen Mitigasi Bencana dengan Teknologi Informasi di Kabupaten Ciamis, Jurnal Keperawatan Unpad, 4(1), 2016, 79-88.

Hasnawir (2012). Ambang Batas Curah Hujan di Kaldera Bawakaraeng, Sulawesi Selatan, Jurnal Penanggulangan Bencana 3(1), 2012, 14- 24.

Komala Dewi, Indarti, \& Istiadi, Yossa (2016). Mitigasi Bencana pada Masyarakat Tradisional dalam menghadapi Perubahan Iklim di Kampung Naga Kecamatan Salawu Kabupaten Tasikmalaya, Jurnal Manusia dan Lingkungan, 23(1), 2016,126-135. 
e-ISSN: 2686-0724 - p-ISSN: 0853-4470 - Vol. 02, No. 02 (2019), pp. 124-132

Johnes, Martin (2005). 'Heads in the Sand': Football, Politics and Crowd Disasters In Twentieth-Century Britain, in Darby, Paul, Johnes, Martin \& Mellor, \& Gavin (ed). Soccer and Disaster: International Perspective. London and New York: Routledge

Haddow, George D. dan Haddow, Kim S. (2009). Disaster Communication in The Changing of Media World. Oxford: Butterworth-Heinemann

K.Yin, Robert (2014). Studi Kasus: Desain dan Metode. Jakarta: Rajawali Pers

Neuman, Lawrence (2000). Social Research Methods: Qualitative and Quantitative Approaches, $4^{\text {th }}$ Edition. Boston: Allyn and Bacon

Sutopo, HB (2000). Metode Penelitian Sosial Kualitatif. Solo: UNS Pers. 